\title{
New triterpene isolated from Eschweilera longipes (Lecythidaceae)
}

\author{
PATRÍCIA M. DA COSTA and MÁRIO G. DE CARVALHO \\ Departamento de Química, ICE, Universidade Federal Rural do Rio de Janeiro \\ 23851-970 Seropédica, RJ, Brazil \\ Manuscript received on May 22, 2002; accepted for publication on November 17, 2002; \\ presented by FERNANDO GALEMBECK
}

\begin{abstract}
The phytochemical studies of Eschweilera longipes Miers (Lecythidaceae) have led to the identification of a new triterpene $3 \beta, 24$-dihydroxyfriedelane, the known $1 \beta, 2 \beta, 3 \beta, 19 \beta$-tetrahydroxyurs-12-en-28-oic acid ( $1 \beta$-hydroxyeucaphic acid) besides the saponin sitosterol $3 \beta \mathrm{O}-\beta \mathrm{D}$-glucopyranoside. The structures were established from the IR, NMR and mass spectra data including 2D NMR experiments of natural substances and of the acetyl derivative of the new triterpene.
\end{abstract}

Key words: Eschweilera longipes, Lecythidaceae, triterpenoids.

\section{INTRODUCTION}

Lecythidaceae is a pantropical family (about 25 genera and 400 species) with the greatest concentration of genera in tropical South America (Brito 1986).

Species of this family have been reported as showing pharmacological activities and the chemical study of some species as Petersianthus macrocarpus, Barringtonia acutangula and Cereya arbo$r e a$, allowed the identification of pentacyclic triterpenes, saponins, elagic acid and indolo[2,1-b]quinazolinic alkaloids (Pant and Rastogi 1979, Das and Mahato 1983, Pal et al. 1991, Massiot et al. 1992 and Bergman 1989).

Eschweilera longipes Miers is a tree that occurs in the north and north-east of Brazil and has been used in the wood industry and in construction. Only triterpenes have been found in the Eschweilera genera. Two previous papers report the isolation of ten known triterpenes along with sitosterol, stigmasterol, $\alpha$-tocopherol and tocotrienol from $E$.

Correspondence to: Dr. Mário Geraldo de Carvalho E-mail: mgeraldo@ufrrj.br longipes (Carvalho et al. 1998) and three pentacyclic triterpenoids which were isolated from the bark and leaves of E. rabeliana (Carvalho et al. 1995).

\section{MATERIALS AND METHODS}

\section{GENERAL EXPERIMENTAL PROCEDURE}

Mp's are uncorrected. NMR spectra were measured in Pyridine- $\mathrm{d}_{6}, \mathrm{MeOD}_{4}$ or $\mathrm{CDCl}_{3}$ solutions and recorded on a Bruker (200 and $500 \mathrm{MHz}$ for ${ }^{1} \mathrm{H}$ and 50.3 and $100 \mathrm{MHz}$ for ${ }^{13} \mathrm{C}$, respectively) and on a GEOL (400 MHz for ${ }^{1} \mathrm{H}$ and $100 \mathrm{MHz}$ for ${ }^{13} \mathrm{C}$ ) spectrometer using TMS as internal standard. High resolution mass spectra were obtained using a VG Auto Spec-300 spectrometer; FT-IR spectra were recorded in $\mathrm{KBr}$ disks on a Perkin-Elmer 1600 spectrometer. Chromatography was performed using Aldrich silica gel with suitable granulation for column and preparative TLC. The visualization of spots was done by UV (254 and $366 \mathrm{~nm}$ ) and exposure to iodine vapor. 


\section{Plant Material}

The wood and leaves were collected in the Amapá State. A voucher specimen $\left(\mathrm{n}^{\circ}\right.$ 00358) is deposited in the Amapaense Herbarium HAMAB of the Museu Angelo Moreira da Costa Lima-IEPA, Macapá, Amapá, Brazil.

\section{EXTRACTION AND ISOLATION}

The dried leaves $(0.7 \mathrm{Kg})$ were extracted exhaustively by $\mathrm{CH}_{2} \mathrm{Cl}_{2}$ maceration at room temperature. The solvent was removed under vacuum to yield a residue $(10.38 \mathrm{~g})$. This residue was chromatographed on silica gel column starting with $\mathrm{CH}_{2} \mathrm{Cl}_{2}$ and successive mixtures of $\mathrm{CH}_{2} \mathrm{Cl}_{2}$-EtOAc, EtOAc$\mathrm{MeOH}$ and finally, $\mathrm{MeOH}$ as eluent to afford 70 fractions of 50 mL each. The 23-40 fractions, eluted with EtOAc-MeOH (9:1), gave a colourless solid (1, $70 \mathrm{mg}, \mathrm{mp} 340^{\circ} \mathrm{C}$ ) which is insoluble in $\mathrm{CDCl}_{3}$. The derivative 1a was prepared dissolving $\mathbf{1}$ in a mixture of pyridine and $\mathrm{Ac}_{2} \mathrm{O}(1: 1)$ and the solution was allowed to stand for $24 \mathrm{~h}$ at room temperature. The usual work-up gave a residue which was dried under vacuum and crystallized from AcOEt to yield the diacetate $\left(\mathbf{1 a}, 65 \mathrm{mg}, \mathrm{mp} 318^{\circ} \mathrm{C}\right)$.

The dried wood $(1.0 \mathrm{Kg})$ was extracted exhaustively by $\mathrm{MeOH}$ maceration at room temperature. The solvent was removed under vacuum to yield a residue $(47.7 \mathrm{~g})$. This residue was dissolved in $\mathrm{MeOH}: \mathrm{H}_{2} \mathrm{O}$ (8:2) and extracted with dichloromethane. The fraction $\mathrm{CH}_{2} \mathrm{Cl}_{2}$ was chromatographed on silica gel column using $\mathrm{CH}_{2} \mathrm{Cl}_{2}$ and successive mixtures of $\mathrm{CH}_{2} \mathrm{Cl}_{2}$-EtOAc, EtOAc-MeOH and finally, $\mathrm{MeOH}$ as eluent to afford 220 fractions of $50 \mathrm{~mL}$ each. The 9-17 fractions, eluted with $\mathrm{CH}_{2} \mathrm{Cl}_{2}$, gave a colourless solid $(2,40 \mathrm{mg}, \mathrm{mp}$ $285^{\circ} \mathrm{C}$ ) soluble in $\mathrm{MeOH}$. The 70-82 fractions, eluted with EtOAc-MeOH (9:1), gave colourless solid (3, 40mg, $\left.\mathrm{mp} 290^{\circ} \mathrm{C}\right)$. The derivative 3a was prepared dissolving $\mathbf{3}$ in a mixture of pyridine and $\mathrm{Ac}_{2} \mathrm{O}(1: 1)$ and working up as usual.

\section{RESULTS AND DISCUSSION}

The chromatographic fractionation of the dichloromethane extract from the leaves of Eschweilera lon- gipes afforded two triterpene, $\mathbf{1}$ and $\mathbf{2}$, besides the saponin sitosterol 3- $\beta \mathrm{O}-\beta$-D-glucopiranoside (3).

The IR spectrum of $\mathbf{1}$ showed absorption bands attributed to hydroxyl $\left(v_{\mathrm{OH}} 3450 \mathrm{~cm}^{-1}\right)$, $v_{\mathrm{C}-\mathrm{O}}\left(1100\right.$ and $\left.1050 \mathrm{~cm}^{-1}\right)$ and very strong $v_{\mathrm{C}-\mathrm{H}}$ at 2950 and $2960 \mathrm{~cm}^{-1}$ suggesting a terpenoid with primary and secondary alcohol. The difficulty to dissolve it in $\mathrm{CDCl}_{3}$ led to prepare the acetyl derivative treating it with pyridine and $\mathrm{Ac}_{2} \mathrm{O}(1: 1)$.

The ${ }^{1} \mathrm{H}$ NMR spectrum of $1 \mathrm{a}$ displayed singlet signals for seven tertiary methyl groups of a pentacyclic triterpene and two signals at $1.96(\mathrm{~s}, 3 \mathrm{H})$ and $2.00(\mathrm{~s}, 3 \mathrm{H})$ of acetyl groups. The signals at 4.40 and $4.60(\mathrm{~d}, \mathrm{~J}=13 \mathrm{~Hz})$ are typical of two methylene hydrogens. The H-3 was represented by the signal at 4.94 (br d, J = 2.4 Hz). The comparative analysis of HBBD and DEPT ${ }^{13} \mathrm{C}$ NMR spectra was used to recognize the signals corresponding to six quaternary carbons, two monoxigenated ${ }^{(} \delta_{\mathrm{CH}} 74.5$ and $\left.\delta_{\mathrm{CH} 2} 65.1\right)$ besides signals of seven methyl, eleven methylene, four methyne groups and two acetyl groups $(\delta 170.1,170.0,21.2$ and 21.1). Those data allowed to propose the molecular formula $\mathrm{C}_{30} \mathrm{H}_{50} \mathrm{O}_{2} \quad\left(\mathrm{O}=\mathrm{C}-\mathrm{CH}_{3}\right)_{2}$ that was confirmed by HRMS with $\mathrm{M}^{+} 528.41740 \mathrm{Da}$ [calcd for $\mathrm{C}_{30} \mathrm{H}_{35}\left(\mathrm{O}_{2} \mathrm{CCH}_{3}\right)_{2}$ 528.41808]. Thus, these spectral data, the $2 \mathrm{D}$ experiments $\left({ }^{1} \mathrm{H}-{ }^{1} \mathrm{H}-\mathrm{COSY},{ }^{1} \mathrm{H}-\right.$ $\left.{ }^{13} \mathrm{C}-\mathrm{COSY}-{ }^{\mathrm{n}} \mathrm{J}_{\mathrm{CH}}, \mathrm{n}=1,2,3\right)$ and comparison with ${ }^{13} \mathrm{C}$ NMR spectroscopic values described in the literature for acetyl friedelinol (Carvalho et al. 1995, Mahato and Kundu 1994 and Ahmad and Atta-urRahman 1994) show the absence of signal at 15.7 $\left(\mathrm{CH}_{3}-24\right)$ in the fridelinol. This observation and the difference of the C-5 and C- 6 chemical shift of 1 and those of acetyl friedelinol led to locate one acetyl group at $\mathrm{C}-24$. The prominent peaks in the HRMS at $\mathrm{m} / z 455\left(\mathbf{1 b}, 21,5 \%, \mathrm{M}-\mathrm{CH}_{2} \mathrm{OCOCH}_{3}\right), 395$ [1c, $8,3 \%$, M- $\left.\left(\mathrm{CH}_{2} \mathrm{OCOCH}_{3}+\mathrm{HOCOCH}_{3}\right)\right], 344$ (1d, $\left.33,9 \%, \mathrm{C}_{25} \mathrm{H}_{44}\right), 274\left(\mathbf{1 e}, 17,3 \%, \mathrm{C}_{20} \mathrm{H}_{34}\right) 255$ (1f, $15 \%)$ and $205\left(\mathbf{1 g}, 23.8 \%, \mathrm{C}_{15} \mathrm{H}_{25}\right)$, Figure 1, also suggested the presence of two acetyl groups in the C- 3 and C- 24 carbons. The NOE observed between $\mathrm{H}-24 / \mathrm{H}-25, \mathrm{H}-24 / \mathrm{H}-23, \mathrm{H}-24 / \mathrm{H}-1$ in the NOESY spectra of $1 \mathbf{a}(3 \beta, 24$-diacetylfriedelane) was used 

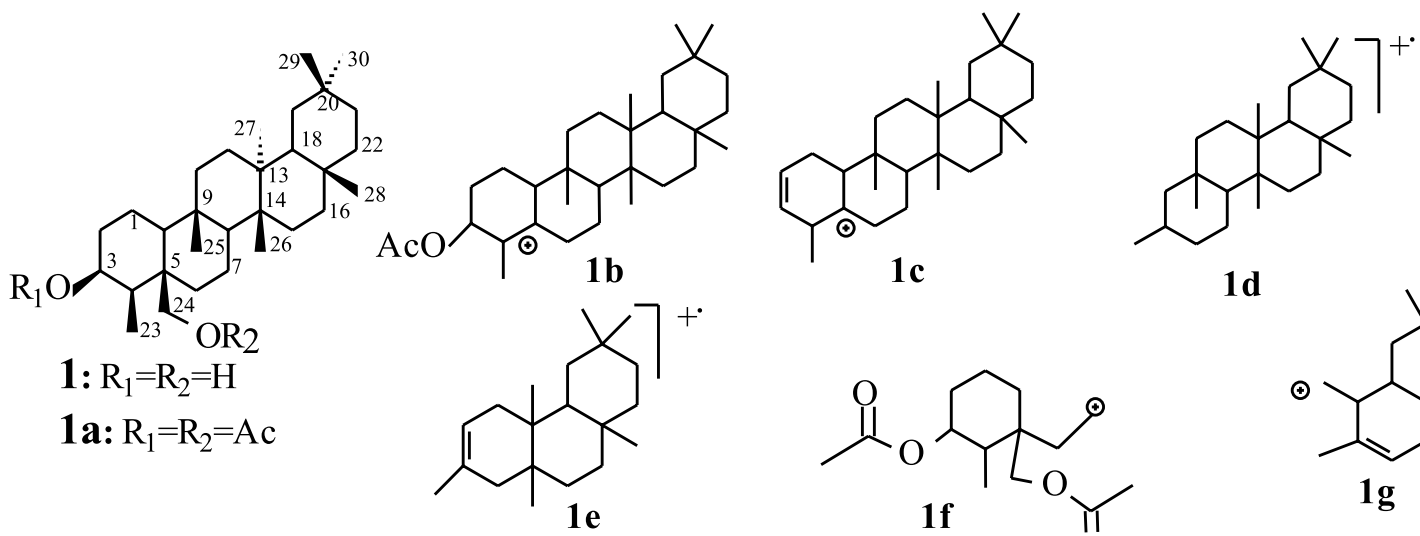

$1 d$<smiles>CC(=O)OCC1(CO)CCCC(OC(C)=O)C1C</smiles><smiles>CC1=CCC2(C)CCC(C)(C)CC2C1O</smiles>

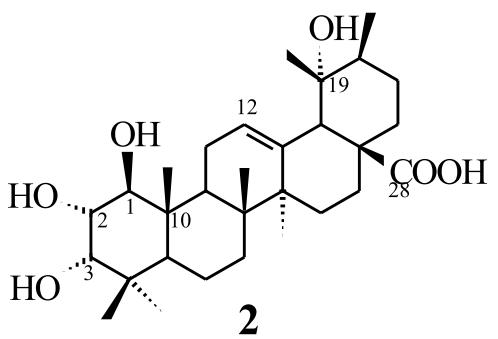

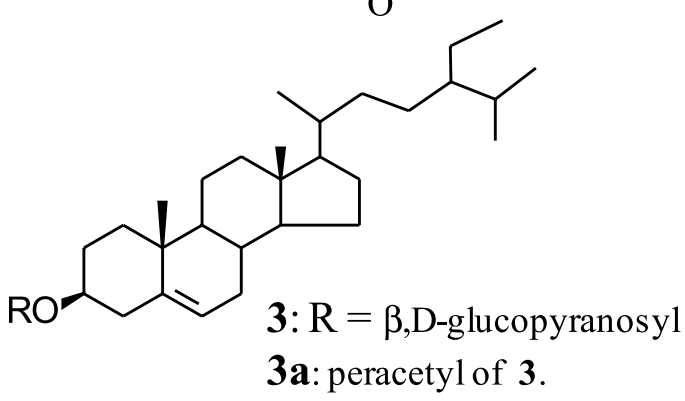

Fig. 1 - Structures for compounds isolated from E. longipes, acethyl derivatives and for prominent peaks in the HRMS.

to confirm the structure of the new triterpene (1) as $3 \beta$,24-dihydroxyfriedelane, Figure 1 . The complete ${ }^{1} \mathrm{H}$ and ${ }^{13} \mathrm{C}$ NMR (1D and 2D) assignments of $\mathbf{1}$ and $\mathbf{1 a}$ are described in Table I.

Compound 2 was characterized as $1 \beta$-hydroxyeucaphic acid by analysis of IR, NMR ${ }^{1} \mathrm{H}$ and ${ }^{13} \mathrm{C}$ (HBBD and DEPT) and 2D experiments $\left({ }^{1} \mathrm{H}^{-1} \mathrm{H}-\right.$ COSY, $\left.{ }^{1} \mathrm{H}^{13} \mathrm{C}-\mathrm{COSY},{ }^{\mathrm{n}} \mathrm{J}_{\mathrm{CH}}, \mathrm{n}=1,2,3\right)$ and EI-MS spectra including comparison of the $\delta_{\mathrm{H}}$ chemical shifts in pyridine registered in the literature (Guang et al. 1989). The NOE signal between $\mathrm{H}-1 / \mathrm{H}-5, \mathrm{H}-$ 1/H-9, H-2/H-24, H-2/H-25, H-3/H-24, H-3/H-23, H-11/H-25, H-18/H-29, H-18/H-12 and H-12/H-29 observed in the NOESY spectrum were used to confirm the structure of 2 as $1 \beta, 2 \beta, 3 \beta, 19 \beta$-tetrahydroxyurs-12-en-28-oic acid. The better resolution of the $\mathrm{ABC}$ system $(\mathrm{H}-2, \mathrm{H}-1$ and $\mathrm{H}-3)$ and the absence of ${ }^{13} \mathrm{C}$ NMR data of $\mathbf{2}$ in the literature led us to make the complete assignment of $\delta_{\mathrm{H}}$ and $\delta_{\mathrm{C}}$ in methanol. The EIMS spectra data were used to confirm the structure. $\delta_{\mathrm{H}}\left(\mathrm{MeOD}_{4}, 200 \mathrm{MHz}\right)$ : 3.39 (d, 8.4Hz, H-1), 3.63 (dd, 8.4 and $3.2 \mathrm{~Hz}, \mathrm{H}-$ 2), 3.45 (d, 3.2 Hz, H-3), 1.3 (m, H-5), 2.1 (m, H9), 5.20 (brs, H-12), 2.47 (s, H-18), 0.96 (s, H-23), 0.87 (s, H-24), 1.00 (s, H-25), 0.78 (s, H-26), 1.34 (s, H-27), 1.18 (s, H-29), 0.92 (d, 6.6Hz, H-30); $\delta_{\mathrm{C}}\left(\mathrm{MeOD}_{4}, 50.3 \mathrm{MHz}\right): 79.9(\mathrm{C}-1), 70.4(\mathrm{C}-2)$, 79.3 (C-3), 39.1 (C-4), 48.2 (C-5), 18.0 (C-6), 32.8 (C-7), 41.2 (C-8), 48.0 (C-9), 37.4 (C-10), 25.2 (C11), 129.3 (C-12), 137.3 (C-13), 43.2 (C-14), 29.4 (C-15), 28.3 (C-16), 48.2 (C-17), 53.3 (C-18), 72.2 (C-19), 41.2 (C-20), 26.9 (C-21), 37.6 (C-22), 27.7 (C-23), 21.0 (C-24), 11.6 (C-25), 16.4 (C-26), 23.5 (C-27), $180.0(\mathrm{COOH}), 25.3(\mathrm{C}-29), 15.2(\mathrm{C}-30)$; EIMS, m/z (\%): 504(10\%), 264(35\%), 246(15\%), 201(45\%), 173(20\%) and 146(100\%).

The spectrometric analysis of IR, ${ }^{1} \mathrm{H}$ and ${ }^{13} \mathrm{C}$ (PND and DEPT) NMR of 3 including comparison with literature data (Chaurasia and Wichtl 1987) were used to identify the saponin $\mathbf{3}$ as sitosterol 
TABLE I

${ }^{1} \mathrm{H}$ and ${ }^{13} \mathrm{C}$ NMR data of the new triterpene (1, Pyridine- $\left.\mathrm{D}_{6}\right)$ and its derivative (1a, $\left.\mathrm{CDCl}_{3}\right)$ using 1D and $2 \mathrm{D}\left({ }^{1} \mathrm{~J}_{\mathrm{CH}},{ }^{1} \mathrm{H}-{ }^{13} \mathrm{C}-\mathrm{COSY}\right.$ and $\left.{ }^{2,3} \mathrm{~J}_{\mathrm{CH}}, \mathrm{COLOC}\right)$.

\begin{tabular}{|c|c|c|c|c|c|}
\hline \multirow[b]{2}{*}{$\mathrm{C}$} & \multicolumn{3}{|c|}{$1 \mathrm{a}$} & \multicolumn{2}{|r|}{1} \\
\hline & $\delta \mathrm{c}$ & $\delta_{\mathrm{H}}^{\mathrm{a}}\left({ }^{1} \mathrm{~J}_{\mathrm{CH}}\right)$ & ${ }^{2,3} \mathrm{~J}_{\mathrm{CH}}$ & $\delta \mathrm{c}$ & $\delta_{\mathrm{H}}^{\mathrm{b}}$ \\
\hline 1 & 16.3 & 1.45 & $\mathrm{H}-3$ & 17.1 & - \\
\hline 2 & 32.1 & $1.90,1.55$ & - & 40.3 & - \\
\hline 3 & 74.2 & $4.94(\mathrm{~d}, 2.4 \mathrm{~Hz})$ & $\mathrm{H}-23$ & 74.7 & $5.25(\mathrm{brs})$ \\
\hline 4 & 48.5 & $1.5(\mathrm{md})$ & $\mathrm{H}-24, \mathrm{H}-23$ & 49.1 & - \\
\hline 5 & 40.6 & - & - & 41.4 & - \\
\hline 6 & 35.8 & $2.3(\mathrm{brd}), 1.5(\mathrm{~m})$ & $\mathrm{H}-24$ & 36.0 & $2.3(\mathrm{~d}, 14 \mathrm{~Hz})$ \\
\hline 7 & 17.6 & 1.40 & - & 19.3 & - \\
\hline 8 & 53.1 & $1.3(\mathrm{brd})$ & H-27, H-6, H-7 & 53.8 & - \\
\hline 9 & 36.9 & - & - & 36.8 & - \\
\hline 10 & 61.1 & $1.1(\mathrm{~m})$ & $\mathrm{H}-25$ & 61.6 & - \\
\hline 11 & 35.7 & $1.2-1.5(\mathrm{~m})$ & H-25 & 36.5 & - \\
\hline 12 & 30.6 & - & - & 31.4 & - \\
\hline 13 & 38.3 & - & - & 37.6 & - \\
\hline 14 & 39.5 & - & H-26 & 39.9 & - \\
\hline 15 & 32.0 & - & - & 32.5 & - \\
\hline 16 & 35.9 & $1.4(\mathrm{~m}), 1.0(\mathrm{~m})$ & - & 35.6 & - \\
\hline 17 & 29.9 & - & - & 30.7 & - \\
\hline 18 & 42.7 & $1.6(\mathrm{dd})$ & H-28 e H-27 & 43.6 & - \\
\hline 19 & 35.2 & $1.3(\mathrm{~m}), 2.3(13 \mathrm{~Hz})$ & - & 35.6 & $2.0(\mathrm{dd}, 14.1,2.4 \mathrm{~Hz})$ \\
\hline 20 & 28.1 & - & - & 28.8 & - \\
\hline 21 & 32.7 & - & - & 32.9 & - \\
\hline 22 & 39.2 & $0.9(\mathrm{~d}), 1.4(\mathrm{~m})$ & H-28 & 39.0 & - \\
\hline 23 & 13.7 & $0.92(\mathrm{~d}, 7 \mathrm{~Hz})$ & $\mathrm{H}-4$ & 14.8 & $1.09(\mathrm{~d}, 7 \mathrm{~Hz})$ \\
\hline 24 & 65.1 & $4.40,4.6(\mathrm{~d}, 13 \mathrm{~Hz})$ & - & 65.8 & $4.61,4.90(\mathrm{~d}, 14 \mathrm{~Hz})$ \\
\hline 25 & 18.3 & $0.85(\mathrm{~s})$ & - & 18.4 & $0.88(\mathrm{~s})$ \\
\hline 26 & 18.6 & 0.96 & - & 18.9 & $1.04(\mathrm{~s})$ \\
\hline 27 & 20.1 & 0.96 & H-8 & 20.8 & $1.07(\mathrm{~s})$ \\
\hline 28 & 32.0 & $1.13(\mathrm{~s})$ & - & 33.6 & $1.18(\mathrm{~s})$ \\
\hline 29 & 35.0 & $0.91(\mathrm{~s})$ & - & 35.6 & $0.90(\mathrm{~s})$ \\
\hline 30 & 31.7 & $0.96(\mathrm{~s})$ & - & 32.7 & $1.0(\mathrm{~s})$ \\
\hline $\mathrm{H}_{3} \underline{\mathrm{C}}-\mathrm{CO}$ & 21.2 & $1.96,2.0$ & - & - & - \\
\hline $\mathrm{H}_{3} \mathrm{C}-\underline{\mathrm{CO}}$ & 170.1170 .0 & & $\underline{\mathrm{H}}_{3} \mathrm{C}-\mathrm{CO}$ & - & - \\
\hline
\end{tabular}

${ }^{\mathrm{a}}$ Other signals were not defined. ${ }^{\mathrm{b}}$ Multiple signal between 1.7-1.2. 
$3 \beta \mathrm{O}-\beta \mathrm{D}$-glucopyranoside, Figure 1.

\section{ACKNOWLEDGMENTS}

The authors are grateful to CNPq, CAPES and FAPERJ for research fellowships and financial support. We thank to CENAUREMN-FINEP (Centro Nordestino de Aplicação e Uso de Ressonância Magnética Nuclear), UFCE, Fortaleza, Ceará, Brazil for ${ }^{1} \mathrm{H}(500 \mathrm{MHz})$ and ${ }^{13} \mathrm{C}(125 \mathrm{MHz}) \mathrm{NMR}$ spectra. We thank to UENF (Universidade Estadual do Norte Fluminense) for ${ }^{1} \mathrm{H}(400 \mathrm{MHz}),{ }^{13} \mathrm{C}(100$ $\mathrm{MHz}$ ), NOESY and MS spectra and to UNICAMP for HR-MS spectra.

\section{RESUMO}

O estudo fitoquímico de Eschweilera longipes Miers (Lecythidaceae) conduziu a identificação de um novo triterpeno $3 \beta, 24$-diidroxifriedelano, do ácido $1 \beta, 2 \beta$, $3 \beta, 19 \beta$-tetraidroxiursa-12-en-28-óico conhecido como ácido $1 \beta$-hidroxieucáfico além da saponina $3 \beta \mathrm{O}-\beta \mathrm{D}$ glucopiranosilsitosterol. As estruturas foram estabelecidas com análise de dados espectrais de IV, massas e RMN incluindo experimentos 2D das substâncias naturais e do derivado acetilado do triterpeno novo.

Palavras-chave: Eschweilera longipes, Lecythidaceae, triterpenoides.

\section{REFERENCES}

Ahmad VU and Atta-ur-Rahman. 1994. Handbook of Natural Products Data, Elsevier, N.Y., Vol. 2, p. 568.

Bergman J. 1989. The Identity of Cardidine and Quingdainone. Phytochemistry 28: 3547-3549.
BRITO NRS DE. 1986. Perfil Químico de famílias Angiosperma, Tese de Doutorado, Instituto de QuímicaUSP, São Paulo, Brasil, p. 268.

Carvalho MG de, Almeida MEL de, Hauptli MB AND Meleiro LAC. 1995. Triterpenos isolados de Eschweilera rabeliana Mori (Lecythidaceae). Rev Univ Rural Ser Ciênc Exatas e da Terra 17 jan/dez: 33-36.

Carvalho MG de, Velandia JR, Oliveira LF de And Bezerra FB. 1998. Triterpenes isolated from Eschweilera longipes Miers (Lecythidaceae). Quím Nova 21: 740-743.

Chaurasia N and Wichtl MJ. 1987. Sterols and Steryl Glycosides from Urtica dioica. J Nat Prod 50: 881885.

Das JL and Mahato SB. 1983. Triterpenoids. Phytochemistry 22: 1071-1095.

Guang Y, Gray AI and Waterman PG. 1989. Pentacyclic Triterpenes from fruits of Rosa sterilis. J Nat Prod 52: 162-166.

Mahato SB AND Kundu AP. 1994. ${ }^{13}$ C NMR Spectra of pentacyclic triterpenoids - A compilation and some salient features. Phytochemistry 37: 1517-1575.

Massiot G, Chen X, Lanand C, Le Men-Olivier L, Delando C, Viari A, Vigny P and Duval J. 1992. Saponins from stem bark of Petersianthys macrocarpus. Phytochemistry 31: 3571-3576.

Pal BC, Achari B and Price KR. 1991. A triterpenoid glucoside from Barringtonia acutangula. Phytochemistry 30: 4177-4179.

Pant P and Rastogi RP. 1979. The triterpenoids. Phytochemistry 18: 1095-1108. 